\title{
The Challenges of Confidentiality and Anonymity in Undertaking Scientific Research
}

\author{
Norman Adamson Sigalla King (Corresponding author) \\ Teofilo Kisanji University \\ Mbeya, Tanzania \\ E-mail: adamsonnorman@gmail.com
}

Newton Kyando

University of Iringa

Iringa, Tanzania

Lucy Massoi

Mzumbe University

Scholar Ghent University, Belgium

Received: March 20, 2014 Accepted: April 28, $2014 \quad$ Published: May 13, 2014

doi:10.5296/ijssr.v2i2.5620 URL: http://dx.doi.org/10.5296/ijssr.v2i2.5620

\begin{abstract}
The importance of confidentiality cannot be understated in conducting research, particularly when using interviews and questionnaires as main instruments of data collection. Trainers and lecturers, the world over, advocate on the importance of preserving secrecy of the respondents. This article reviews the essence of confidentiality, and discusses the advantages and disadvantages of confidentiality. The study is explorative in nature, and utilises experiential as the main source of data gathering. We conclude that while confidentiality has been seen as important in researches, there are possibilities that confidentiality may hamper the true position of the research, and in addition, it creates possibility for research cheating since respondents cannot, in essence, be verified. We therefore appeal for the contemporary world scientist to look on revealing the names of respondents for ascertaining reliability and validity of the information gathered. In addition, with modern tools of data analysis and interpretation, there are possibilities of manipulating information of previous studies without
\end{abstract}


doing a fieldwork, because one may be protected by the poor use of some research ethics such as confidentiality. We appeal to research supervisors to do their work imitating what referees in games such as football would do when ensuring that every thing is observed in conformity to rules of the ground. Otherwise, we are likely to see research dissertations/thesis accepted and even published, as if goals accepted even when the entire audience notes that it was a clear hand used to insert the ball to the net.

Keywords: Anonymous, confidentiality, data analysis, findings, research

\section{Introduction}

Research literally refers to a search for knowledge. Re-search means search again. Hence, research would refer to search for more knowledge, and can be done repeatedly. It includes going deep in the investigation of the matter. Therefore, research is a careful investigation or enquiry especially through search for new facts in any branch of knowledge. Saunders et al (2009) defines research as something that people undertake in order to find out things in a systematic way, thereby increasing their knowledge. Research is defined as the creation of new knowledge and/or the use of existing knowledge in a new and creative way to generate new concepts, methodologies and understandings. This could include synthesis and analysis of previous research to the extent that it leads to new and creative outcomes (Commonwealth, 2010).

Hence, researches are systematic because they observe logical relationships, which include describing, explaining, understanding, criticising, analysing, and not just beliefs (Ghauri and Gronhaug, 2005).

Researches are well understood to be potential the world over. We notice the importance of researches in informing the societies on the pertinence of issues that we address. It is of no doubt that without researches we cannot tackle issues of the total development of livelihood of the people. This could, of course be the case, when such researches stem from problems that face our societies. Proper problem solving must cement on the researches that are pursued. On pursuing researches, there are steps that we all agree that are worthy to be observed, including concealing respondents. In this regard, we do not reveal the names of respondents unless the interviewee has voluntarily agreed to be revealed. We assume that some respondents would be reluctant to reveal their names or would not want their names revealed.

Confidentiality in research means that only the investigator(s) or individuals collecting/analyzing data can identify the responses of individual subjects; however, the researchers must make every effort to prevent anyone outside of the project from connecting individual subjects with their responses. In other words, the researcher but not the entire public knows respondents, which are equally a beneficiary of the findings and analyses (CUNY, 2012; Norman, 2005). In addition, confidentiality means that the researcher can identify the participant but access to this information will not go beyond the researcher.

Anonymity in research means that either the researcher does not collect identifying information of individual subjects such as name, address, email address among others, or the 
researcher cannot link individual responses with participants' identities (RU, 2012; CUNY, 2012; Norman, 2005). In other words, anonymity means that the participant cannot be identified by anyone, including the researcher. In the past we had arguments on the meaning of confidentiality and anonymity. Currently we believe that there is no contestation on the two terms, as meanings of the two are well tackled in current literatures (Crow and Wiles, 2008; Wiles et al., 2006; Rogelberg, Spitzmueller, Little, \& Reeve, 2006; Cho \& LaRose, 1999; Joinson, Woodley, \& Reips, 2007; Sills \& Song, 2002; Thompson \& Surface, 2007; Thompson, Surface, Martin, \& Sanders, 2003).

Here some questions emerge. Why do people shy off from revealing their names? Supposedly, the responses are true and have been given through positive spirit what will make the respondent shy from revealing the name. What are the impacts of anonymous in research? What is the difference in terms of responses when one knows that the name will be revealed and when the same knows the name will be concealed? What makes some dignitaries challenge academic researches? What do media people do to come up with top news in our societies? If our researches were to be published daily in our daily newspapers, would they draw attention of the people? Why is it that journalist would come up with stories/news that seem to be informative than most researches would do? What is the secret behind it?

The study, which is the review in nature, does an attempt to come up with the impact of concealing names in researches, and suggests a way forward.

\section{Literature Review}

Ethics in research is crucial for enhancing both legitimacy and acceptability of the entire research. In this view McTavish and Loether (2002) provides that two sources determine ethical behaviour. The sources are the investigator, and the societal context in which the research is conducted. They add that most researchers feel two things that bring pressure unto them. First, doing the best possible job of inquiry so that solid findings are established; second, treating those involved in research in humane and appropriate way.

Few literatures provide the do not in researches, especially when referring to what it constitute confidentiality. Various Associations, however, have tried to come up with what it takes in confidentiality. One of the most elaborative is the American Sociological Association (ASA's). Article 11 of the code of conduct in research reveals that:

Sociologists have an obligation to ensure that confidential information is protected. They do so to ensure the integrity of research and the open communication with research, teaching, practice, and service. When gathering confidential information, sociologists should take into account the long term uses of the information, including its potential placement in public archives or the examination of the information by other researchers or practitioners.

We notice that apprehending confidentiality of information in relation to the source can be applauding. However, what remain uncertain is holding confidential of the sources. The ASA's (section 11.01) further narrates in details what it takes to maintaining confidentiality. It reveals that: 
a) Sociologists take reasonable precautions to protect the confidentiality rights of research participants, students, employees, clients, or others.

b) Information provided under an understanding of confidentiality is treated as such even after the death of those providing that information.

The narration above seem worthy in protecting the participants in researches. It does however, little in anticipating the dangers of such protection.

Article (10.11.06) provides the essence of anonymity of sources.

a) When confidential information is used in scientific and professional presentations, sociologists disguise the identity of the research participants, students, individual or organisation clients, or other recipients of their service.

b) Sociologists plan so that confidentiality of research, data, or information is protected in the event of the sociologist's death, incapacity, or withdrawal from the position or practice.

In the same vein, Saunders et al (2009:180) add that researchers are concerned with the confidentiality of the data that would have to be provided and the anonymity of the organisation or individual participants. Many other literatures indicate the importance of anonymity of the participants in research. The series include (Clough \& Nutbrown, 2002; Adams \& Schvaneldt, 1991; Anderson et al., 1999; American Psychological Association, 2005; Anderson, 2003).

\section{Materials and Methods}

This article is a review, hence has adopted a qualitative research approach, and it is an explorative in nature. It has no prior hypothesis to test, rather intends to come up with one through exploration. It has utilised documentation and experiential as the main sources of data gathering. Inquisitions regarding justification for confidentiality have been the key in enumerating the value pegged to the researches. Testing the value of information in the environmental setting in which we are orientated has been one of the cause for this study. This study articulates a pragmatism philosophy as it contend on studying what we are interested, and is of value to our academic society, study in different ways in which we deem appropriate for coming up with results that would yield knowledge worthy to improve our research approaches (Tashakkori \& Teddie, 1998:30).

\section{Results and Discussion}

The various literatures seem to prophesy the need for confidentiality in undertaking research. However, the totality of what is advocated is an assumption that people are not willing to reveal their personalities because can, in one way or another, endanger their lives. The second assumption is that revealing names or personalities may frighten respondents not to properly participate in the studies. The third is the cause effect response in that those who may volunteer responding would do so at the expense of not revealing speckling information or information that is perceived to endanger their lives. The assumptions made above lead us 
into expounding the essence of the doubts by posing three corresponding questions, with the thrust of giving suggestive propositions on the same. The first question is why should one fear to reveal the truth at the expense of revealing his or her name? If confidentiality and /or anonymity would continue prevailing, how do we attest the findings? How do we do away with the perceived research cheating conducted in the four corners of the room with none existing respondents?

\section{Why should one fear to reveal his or her name?}

In our normal setting in which we live, such as work places, homes, and games, we experience that people tend to fear revealing the perceived bad information of the object under study, especially when such study is behavioural in nature and specifically when it connote bad behaviour. In addition, we fear revealing information when such study is in relation to the people whom we know and we perceive that if one would trace back, it would be evident that we were the source of the information. Moreover, the tendency of most people is to fear revealing information that are bad or negate the behaviour of the object. However, we seem not to fear coming front when we reveal information that is positive in relation to the object under study. It is from this stance, firm inquisitions are needed. People differ in terms of honouring truth. Some will stand at their truth even at the expense of their death. Some naturally do not honour the truth. We understand that even at our work places, we have some workers, subordinates, or superiors whom we echo because they stand by the truth, and would stand to be corrected.

These workers do not fear presenting the truth they know. Some because of fear of internalising they can quickly come up with cheap answers. Some because of inability to assess the impact of what they say can stem on what they hear, without confessing that is what they hear. Indeed, we need some studies that are behavioural in nature to assess the human tendencies on concealing and revealing information. We may need to understand factors leading to hesitating being known as key informants.

It is important to register that weighing information acquaintance to most people whom we live with but who are educated in the area they are interviewed, a difference is noted. Most people when are interviewed in relation to their areas of competence are more than ready to have their names put forward. We learn this in several researches. We had an opportunity to interview one president of East Africa on factors they use to make appointment and or promotion of the political leaders-leaders appointed to higher offices such as ministers. When we asked him, should we write your name as a respondent on this issue? "Yes why not, it must be known that it is me who has said so.," remarked his Excellency (Norman, 2012:213). We conducted a study on the extent of the use of financial information in investing in stock exchange in Tanzania in some selected regions. When we arrived in Iringa municipal council, we met one of the investor who fortunately served as a minister in former governments in Tanzania. He made his responses. When we asked him whether we should conceal his name or mention, he said "why conceal, I must be judged in accordance to my words. People should know it is me who has encountered that response be it good or bad" finished the former minister (Norman, 2012:189). However, when such questions are posed to the inferior 
person in terms of knowledge, the tendency would be unwillingness to disclose the name for fear of being caught a liar [we presume], and thus endangering his or her life.

With modern technologies of both data analysis and interpretation, and with numerous educated people who can earn their daily bread through what is perceived as 'consultancy' one can earn a degree through research done 'indoors' through the hands of others or his. We argue therefore that new paradigms need to emerge for respondents to reveal their names. We may, in future, if not now appeal for names being part of the study report. We feel pleased when we conducted a research on administrative plant strategies in the big four regions in 1995 in Tanzania, and appended to the report all names of the interviewee whom we met during the study (Milanzi \& Norman, 2012).

Some questions are critical. Scientific researches appeal for another person to replicate the methodologies or methods used in one study in another setting or even the same setting (Saunders et al., 2009; Pinsonneault \& Nelson, 1997; Kothari, 2003; Creswell, 2003; Gonje et al., 2012). If we contend that interviewee should be held confidential and/or anonymous, one can deviate some information in one completed work, and conclude supporting or negating the former study pending his or her wish. We notice that development is obvious when research observes scientific stance, which indeed need to be updated to conform to the realities on the field so that alteration and manipulation of data should not influence the findings and analysis negatively.

\section{Conclusion}

We are now in position to make suggestive conclusions. We have noted that under the current modernity or technological advancement in terms of tools for data analysis, which in one way have improved and eased the time for doing researches, including time for analysing and interpreting data, equally has created space for possible immoral manipulation of the data using analytical tools. If we indulge into maintaining confidentiality, we might create the perceived well-written dissertation and thesis, which have untrue foundation especially on the responses or participants. It is high time to have few respondents who are ready to be revealed than a bulk of them whom we shield under the cover of confidentiality, while they may not be in existence. Alternatively, we must have some stages of confidentiality. For example, supervisor must be given access to know who responded. When a researcher confides himself and we supervisors presuppose that the attainment of data observed what we consider scientific attribute of confidentiality, without having any level of checks and balances, we might qualify cheats to be part of science. Studies are suggested in the area of the impact of confidentiality on modern society with concentration on 'can we really trace the respondents/participants'. We elude that for researches to benefit the people, must be done to reveal the truth of the problem setting than a current concentration of observance of methodologies without tackling what is considered the source of the problem. We notice that truth sets people free. 


\section{Macrothink}

International Journal of Social Science Research

ISSN 2327-5510

2014, Vol. 2, No. 2

\section{References}

Adams, G., \& Schvaneveneldt, J. (1991). Understanding Research Methods (2nd ed.). New York: Longman.

American Psychological Association. (2005). Concise rules of the APA style. Washington, DC: American Psychological Association

Anderson, D. R., Sweeney, D. J., \& Williams, T. A. (1999). Statistics for business and economics (7th ed). Cincinnati, OH: South-Western College Publishing.

Becker, H. (2008). Writing for social scientists. Chicago, IL: University of Chicago Press.

Beeton, S. (2005). Film-induced Tourism. Clevedon: Channel View Publication.

Cho, H., \& LaRose, R. (1999). Privacy issues in internet survey. Social science Computer Review, 17, 421-434. http://dx.doi.org/10.1177/089443939901700402

Commonwealth. (2010). Importance of research and development. Marlborgh House: Commonwealth

Couper, M. P., Singer, E., \& Tourangeau, R. (2003). Understanding the effects of Audio-CASI on self-reports of sensitive behaviour. Public Opinion Quarterly, 67, 385-395. http://dx.doi.org/10.1086/376948

Creswell, J. (2003). Research designing qualitative, quantitative and mixed methods approaches (2nd ed.). Lincoln: University of Nebraska.

Crow, G., \& Wiles, R. (2008). Managing anonymity and confidentiality in social research: the case of visual data in community research. ESRC National Centre for Research Methods (NCRM). Working paper series 8/08.

Ghauri, P., \& Gronhaug, K. (2005). Research methods in business studies: A practical Guide (3rd ed.). Harlow: Financial Times Prentice Hall.

Gonye, J., Mareva, R., \& Dudu, W. T. (2012). Academic Challenges in Zimbabwe: A case study of great Zimbabwe University. International Journal of English and literature, 3(3), 71-83.

Joinson, A. N., Woodley, A., \& Reips, U. D. (2007). Personalisation, authentication and self -disclosure in self-administered internet surveys. Computers in Human Behaviour, 23, 275-285.

Kothari, C. R. (2004). Research Methodology: Methods and Techniques (2nd ed.). New Delhi: New age international publishers.

McTavish, D. V., \& Loether, H. J. (2002). Social Research: An Evolving Process. London: Pearson Education Inc.

Milanzi, M. C., \& Norman, A. S. K. (2012). Administrative plant strategies in Tanzania: A focus on the big four regions. Dar es Salaam: TREECARE. 
Norman, A. S. (2005). Development is a war: What do we do? Dar es salaam: TREECA.

Norman, A. S. (2006). Inauguration speech for the residing water levels conference on the Lake Victoria Basin, held in Kisumu, Kenya on 25 November 2006.

Norman, A. S. K (2012). The use of financial information in investment decisions making in capital markets in Tanzania. PhD dissertation, OUT: Dar es Salaam

Pinsonneault, A., \& Nelson, H. (1997). Anonymity in Group Support Sy'stems Research: A New Conceptualization, Measure, and Contingency Framework. Journal of Management Information Systems, 14, 89-108.

Rogelberg, S. C., Spitzmueller, C., Little, I., \& Reeve, C. L. (2006). Understanding response behaviour to an online special topics organisational satisfaction survey. Personnel Psychology, 59, 903-923. http://dx.doi.org/10.1111/j.1744-6570.2006.00058.x

Saunders, M., Lewis, P., \& Thornhill, A. (2009). Research methods for business students (5th ed.). London: Pearson Education

Sills, S. J., \& Song, C. (2002). Innovations in survey research: An applicaton of web based surveys. Social Science Computers Review, 20, 22-30. http://dx.doi.org/10.1177/089443930202000103

The City University of New York. (2012). Anonymity vs. confidentiality. Collaborative program research and evaluation. CUNY.

Thompson, L. F., Surface, E. A., Martin, D. L., \& Saunders, M. G. (2003). From paper to pixels: Moving personnel surveys to the Web. Personnel Psychology, 56, 197-227. http://dx.doi.org/10.1111/j.1744-6570.2003.tb00149.x

Thomson, L. F., \& Surface, E. A. (2007). Employee surveys administered online: Attitudes toward the medium, nonresponse, and data representativeness. Organisational Research Methods, 10, 241-261. http://dx.doi.org/10.1177/1094428106/294696

Whelan, T. J. (2007). Anonymity and confidentiality: Do survey respondents know the difference? Poster presented at the $30^{\text {th }}$ annual meeting of the society of southern social psychologist, Durhan, NC.

Wiles, R., Crow, G., Heath, S., \& Charles, V. (2006). Anonymity and confidentiality. Paper presented to the ESRC Research Methods Festival, Oxford.

\section{Copyright Disclaimer}

Copyright reserved by the author(s).

This article is an open-access article distributed under the terms and conditions of the Creative Commons Attribution license (http://creativecommons.org/licenses/by/3.0/). 